\title{
EFEKTIFITAS EKSTRAK ETANOL DAUN SAWI HIJAU (Brassica rapa Var. Parachinensis) SEBAGAI PELEMBAB KULIT DENGAN SEDIAAN MASKER PEEL-OFF
}

\author{
Cucu Arum Dwi Cahya ${ }^{1}$, Aminah Syarifuddin², Ahmad Syukur \\ Hasibuan ${ }^{3}$ \\ Institut Kesehatan Medistra Lubuk Pakam \\ E-mail :cucuarumm22@gmail.com \\ DOI : https://doi.org/10.35451/jfm.v2i1.292
}

\begin{abstract}
Green mustard plants can be formulater into peel-off masks to moisturize the skin, because based on previous research green mustard leaves cointain flavonoids as antioxidants which can moisturize the skin. The purpose of this study was to find out green mustard leaves can be formulated into peel-off mask preparations and to find out the preparation and to find out the preparation off peel off mask with etanol extract of green mustard leaves can moisturize the skin. This study uses an experimental method. Green mustard leaves are extracted by maceration. In this study, a skin analyzer was usee as a mesure of skin moisture level after using peel off mask from a variety of dosage formulations which were divided into 5 preparations, blank (without mask, 3\%,4\%,5\%), postive control (using peel off masks on the market). The Anova test results show a sig value of 0,000 or $p<0,005$ so it is concluded that the variabel has a difference. The conclusion of this study proves that the ethanol extract of green mustard leaves can be used as a peel-off mask for skin moisturizer, where the higher the concentration of mustard leaf extract, the higher the moisture vlue of the skin.
\end{abstract}

Keywords: peel-off mask, green mustard leaf extract, skin moisturize.

\section{Pendahuluan}

Sawi memiliki banyak varietas, namun yang biasa dibudidayakan di Indonesia antara lain, sawi hijau, sawi putih, dan pakcoy. Bentuk dan ukuran masing-masing varietas berbeda, bahkan umur panen pun berbeda. Umumnya sawi memiliki daun yang lonjong, halus, tidak berkrop, dan tidak berbulu. Di Indonesia, petani hanya mengenal dan biasa membudidayakan 3 jenis sawi yaitu sawi putih, sawi hijau, dan pakcoy. Sawi mencakup beberapa spesies Brassica yang kadang-kadang mirip satu sama lain. Di Indonesia penyebutan sawi biasanya mengacu pada sawi hijau (Brassica rapa) kelompok parachinensis, yang disebut juga sawi bakso, caisim, atau caisin. Selain itu, terdapat pula sawi putih (Brassica rapa) kelompok pekinensis, disebut juga petsai. Biasa dibuat sup atau diolah menjadi asinan. Sawi sendok (pakcoy) merupakan jenis sayuran daun kerabat sawi yang mulai dikenal pula dalam dunia boga Indonesia (Pracaya, 2011).

Sawi merupakan jenis sayur yang digemari oleh masyarakat Indonesia. Konsumennya mulai dari golongan masyarakat kelas bawah hingga 
golongan masyarakat kelas atas. Sayuran sawi yang dikonsumsi, setelah diolah, mengandung beragam zat makanan yang esensial bagi kesehatan tubuh. Selain itu memiliki kandungan vitamin dan zat gizi yang penting bagi kesehatan (Haryanto et al., 2002).

\section{Kandungan Sawi Hijau}

Kandungan daun sawi hijau diantaranya vitamin A, Vitamin C, dan Flavonoid sebagai antioksidan (Kloppenburg, 2009; Marbun, et al, 2018). Sawi hijau sebagai bahan makanan sayuran mengandung zat-zat gizi yang cukup lengkap sehingga apabila dikonsumsi sangat baik untuk mempertahankan kesehatan tubuh (Pulungan, et al., 2018).

\section{Masker}

\section{Pengertian Masker}

Masker atau topeng ditujukan untuk penggunaan kulit, terutama wajah dan leher. Masker bisa dalam bentuk pasta (setengah padat) atau cairan yang kemudian dioleskan secara merata dan dibiarkan hingga mengering.

\section{Masker Peel Off}

Masker Peel-Off biasanya dalam bentuk gel atau pasta, yang dioleskan ke kulit muka. Setelah alkohol yang terkandung dalam masker menguap, terbentuklah lapisan film yang tipis dan transparan pada kulit muka. Setelah berkontak selama 15-30 menit, lapisan tersebut diangkat dari permukaan kulit dengan cara dikelupas (Slavtcheff,2000).

Masker peel off memiliki beberapa manfaat diantaranya, merileksasikan otot-otot wajah, membersihkan, menyegarkan, melebabkan dan melembutkan kulit wajah (Vieira, Rafael Pinto, 2009). Selain itu Penggunaan masker wajah peel off bermanfaat untuk memperbaiki serta merawat kulit wajah dari masalah keriput, penuaan, jerawat dan dapat juga digunakan untuk mengecilkan pori (Grace Grace, F.X, C.Darsika, K.V.Sownya, K.Suganya amd S.Shanmuga Nathan, 2015).

Masker wajah peel off merupakan salah satu jenis masker wajah yang mempunyai keunggulan dalam penggunaanya yaitu dapat dengan mudah dilepas atau diangkat seperti membrane elastis (Rahmawanty dkk., 2015). Hal ini juga sudah diperkuat dengan pendapat (Harry,1973) yang menyatakan Masker peel off juga mempuntai bebrapa keuntungan diantaranya penggunaan yang mudah, serta mudah dibilas dan dibersihkan. Selain itu, dapat juga diangkat atau dilepaskan seperti membrane elastic.

\section{Metode Penelitian}

\section{Jenis dan Rancangan Penelitian}

Jenis penelitian ini adalah eksperimental. Dengan melihat nilai kelembaban kulit dengan perbandingan kosnentrasi $3 \%, 4 \%$, dan $5 \%$ menggunakan alat Skin Analyzer. Penelitian ini diuji juga menggunakan uji Anova untuk melihat nilai perbandingan.

\section{Lokasi Penelitian}

Penelitian ini dilakukan dibeberapa tempat, diantaranya :

1. Laboratorium Kimia Organik Program Studi Farmasi Fakultas Farmasi Institut Kesehatan Medistra Lubuk Pakam digunakan untuk proses maserasi dan skrining fitokimia

2. Laboratorium Farmasetika Program Studi Farmasi Fakultas Farmasi Institut Kesehatan Medistra Lubuk Pakam digunakan untuk proses pembuatan sediaan masker peel-off

\section{Sampel Penelitian}

Sukarelawan yang dijadikan panel pada pengujian sediaan masker peel-off sebagai pelembab kulit berjumlah 18 orang dengan 6 kelompok perlakuan yang terdiri dari 3 orang setiap 
kelompok. Teknik pengambilan sampel yang digunakan adalah non-probability sampling dengan pendekatan teknik purposive sampling dengan kriteria sebagai berikut :

1. Wanita yang tidak memiliki riwayat alergi

2. Memiliki karakteristik/kriteria yang teridentifikasi kulit kering

3. Bersedia menjadi sukarelawan dan menandatangani lembar persetujuan

\section{Metode Pengumpulan Data}

Metode pengumpulan data dalam penelitian ini menggunakan metode dengan cara observasi langsung.

\section{Prosedur Penelitian}

Alat-alat

Alat-alat yang digunakan dalam penelitian ini adalah batang pengaduk, beaker glass, blender, gelas ukur, hotplate, kertas saring, lumpang, pipet tetes, rotary evaporator, skin analyzer, spatula, stamper, tabung reaksi, timbangan analitik, waterbath.

\section{Formulasi Sediaan Masker Peel-Off Formulasi Standar Masker Peel-Off (Rieger, 2000)}

R/ Polivinil Alkohol 5-10\%

$\begin{array}{ll}\text { Humektan } & 2-10 \% \\ \text { Surfaktan } & 2-5 \% \\ \text { Alkohol } & 10-30 \% \\ \text { pH buffer } & \text { pH 4-7 } \\ \text { Pengawet } & \text { qs } \\ \text { Parfum } & \text { qs } \\ \text { Pewarna } & \text { qs } \\ \text { Air Suling } & \text { ad } 100\end{array}$

\section{Formulasi Modifikasi}

$\mathrm{R} /$ Polivinil Alkohol $10 \mathrm{~g}$

HPMC $\quad 1 \mathrm{~g}$

Propilenglikol $10 \mathrm{~g}$

Metil Paraben $0,2 \mathrm{~g}$

Propil Paraben $0,5 \mathrm{~g}$

Ekstrak Daun Sawi $x$

Aquadest ad 100

\section{Pembuatan Formulasi Sediaan Masker Peel-Off}

Dikembangkan PVA dalam aquadest panas, kemudian di aduk hingga homogen $\left(M_{1}\right)$ Dikembangkan pula HPMC dalam aquadest panas hingga mengembang $\left(\mathrm{M}_{2}\right)$. Propilenglikol, Metil Paraben, Propil Paraben dilarutkan dalam aquadest panas $\left(\mathrm{M}_{3}\right)$ Dicampurkan $M_{2}$ dan $M_{3}$ ke dalam $M_{1}$ diaduk hingga homogen. Ditambahkan esktrak daun sawi hijau kedalam $M_{1}$ sedikit demi sedikit hingga homogen. Kemudian tambahkan etanol $96 \%$ dan parfum secukupnya

\section{Evaluasi Sediaan Masker Peel-Off}

\section{Pengujian Organoleptis}

Pengujian organoleptis dilakukan dengan mengamati perubahanperubahan bentuk, warna, dan bau dari sediaan masker gel (septiani, 2011).

\section{Pengujian Homogenitas}

Pemeriksaan homogentias dilakukan dengan cara meletakkan sediaan diantara dua kaca objek dan diamati ada atau tidaknya partikel kasar yang terdapat dalam sediaan (kuncari, 2014)

\section{Pengujian pH}

Dilakukan dengan menggunakan stik pH universal yang dicelupkan kedalam sampel yang telah dilarutkan dengan aquadestilata. Setelah tercelup dengan sempurna, $\mathrm{pH}$ universal tersebut dilihat perubahan warnanya dan cocokan dengan indikator $\mathrm{pH}$ universal. Persyaratan $\mathrm{pH}$ untuk kulit yaitu 4,5 6,5 (Tranggono, 2007).

\section{Pengujian Daya Sebar}

Pengujian daya sebar dilakukan untuk mengetahui kecepatan penyebaran gel pada kulit saat dioleskan pada kulit. Sebanyak 1 gram sediaan gel peel-off 
diletakkan dengan hati-hati diatas kaca berukuran $20 \times 20 \mathrm{~cm}$. Selanjutnya ditutupi dengan kaca yang lain dan digunakan pemberat diatasnya hingga bobot mencapai 100 gram dan diukur diameternya setelah 1 menit. Persyaratan daya sebar yaitu antara 5 $7 \mathrm{~cm}$ (Garg A, Deepeka A, Garg S. Singla $A k, 2002)$.

\section{Pengujian Iritasi}

Sukarelawan yang akan menggunakan kosmetika baru dapat dilakukan uji iritasi, yaitu dengan memakai kosmetika tersebut di tempat lain misalnya di bagian lengan bawah atau di belakang daun telinga. Setelah dibiarkan 24 jam tidak terjadi reaksi kulit yang tidak diinginkan, maka kosmetik tersebut dapat digunakan (wasitaatmadja, 1997).

\section{Pengujian Waktu Mengering}

Pengujian waktu mengering dilakukan dengan cara mengoleskan masker gel peel-off ekstrak daun sawi hijau ke bagian wajah dan amati waktu yang diperlukan sediaan untuk mengering, yaitu waktu dari saat mulai dioleskannya masker gel peel-off hingga benar-benar terbentuk lapisan yang kering. Persyaratan untuk waktu sediaan mengering yaitu selama 15 - 30 menit (Slavtcheff, 2000).

\section{Uji Kemampuan Sediaan untuk Melembabkan Kulit}

Kemampuan sediaan untuk melembabkan kulit dilakukan pada sukarelawan menggunakan alat Skin Analyzer dengan cara berikut: wajah terlebih dahulu di cuci bersih, kemudian dikeringkan hingga benar-benar kering. Dicek persen kelembaban kulit sebelum dioleskan sediaan masker peel-off, dan dicatat persentase yang ditunjukan pada alat. Sediaan masker dioleskan merata pada wajah. Dibiarkan hingga masker benar benar terpenitrasi dikulit kurang lebih 15-30 menit. Dicek kembali persen kelembaban setelah dioleskan sediaan masker dicatat kembali persentase yang ditunjukan oleh alat Skin Analyzer.

\section{PEMBAHASAN}

\section{Hasil Ekstraksi Daun Sawi Hijau}

Hasil yang didapatkan dari proses ekstraksi dari $5 \mathrm{~kg}$ daun sawi hijau dengan menggunakan pelarut etanol $96 \%$ yang dipekatkan dengan rotary evaporator pada suhu $\pm 80^{\circ} \mathrm{C}$ yaitu berupa ekstrak 160gr.

Menurut penelitian yang telah dilakukan Helmi (2014) ,maserasi sampel dilakukan dengan menggunakan pelarut etanol karena sifatnya yang mampu melarutkan hamper semua zat ,baik yang bersifat polar dan non polar. Etanol yang digunakan adalah etanol $96 \%$ yang lazim digunakan untuk ekstraksi sampel yang segar. Serta melalui proses maserasi, ekstrak diuapkan dengan rotary evaporator untuk menguapkan pelarut air yang masih tersisa sehingga didapatkan ekstrak kental.

\section{Hasil Skrining Fitokimia}

Uji skrining fitokimia dilakukan untuk mengetahui golongan senyawa metabolit sekunder yang terdapat pada daun sawi hijau. Hasil uji skrining fitokimia dapat dilihat pada tabel 4.1

\section{Tabel 4.1Hasil Uji Skrining Fitokimia Daun Sawi Hijau}

\begin{tabular}{|c|c|}
\hline $\begin{array}{c}\text { Ekstrak Daun } \\
\text { Sawi Hijau }\end{array}$ & Keterangan \\
\hline Flavonoid & $\begin{array}{c}+ \text { (warna kuning } \\
\text { dan memisah) }\end{array}$ \\
\hline
\end{tabular}

Hasil uji skrining fitokimia daun sawi hijau positif mengandung flavonoid. Menurut Kaban (2015), flavonoid positif jika filtrate sampel ditambahkan serbuk Mg, asam klorida dan amil alkohol, 
dikocok dan dibiarkan memisahakan terbentuk warna kuning.

\section{Hasil Uji Homogenitas}

Hasil uji homogenitas dapat dilihat pada tabel 4.2

Tabel 4.2 Hasil Uji Homogenitas

\begin{tabular}{|c|c|c|}
\hline No & Konsentrasi & Homogenitas \\
\hline 1 & Blanko & $\checkmark$ \\
\hline 2 & $3 \%$ & $\checkmark$ \\
\hline 3 & $4 \%$ & $\checkmark$ \\
\hline 4 & $5 \%$ & $\checkmark$ \\
\hline
\end{tabular}

Pemeriksaan homogenitas bertujuan untuk mengamati ada atau tidaknya partikel kasar pada sediaan. Dari konsentrasi 3\%, 4\%, $5 \%$ dan blanko memiliki homogenitas yang baik, karena tidak ditemukan adanya partikel kasar pada sediaan masker peel-off ekstrak daun sawi hijau (Kuncari,2014)

\section{Hasil Uji pH}

Nilai $\mathrm{pH}$ dari keempat sediaan masker peel-off ekstrak etanol daun sawi hijau adalah 6. Sediaan masker peel-off tidak menyebabkan iritasi karena penggunaannya tidak terlalu lama ( \pm 30 menit) dan $\mathrm{pH}$ yang dihasilkan mendekati $\mathrm{pH}$ kulit yakni 4,5-6,5 (Tranggono,2007)

\section{Hasil Uji Daya Sebar}

Hasil uji daya sebar dari semua konsentrasi baik 3\%, 4\%, 5\% dan blanko memiliki nilai daya sebar $5 \mathrm{~cm}$. Sesuai dengan persyaratan daya sebar yaitu 5-7cm (GargA, Deepeka A, Garg S. Singla $A k, 2002)$

\section{Hasil Uji Iritasi}

Berdasarkan hasil uji iritasi yang dilakukan oleh sukarelawan yang dilakukan dengan mengoleskan sediaan masker peel-off ekstrak daun sawi hijau dibelakang telinga, menunjukkan bahwa semua sukarelawan memberikan hasil negative terhadap parameter reaksi iritasi. Parameter yang diamati yaitu adanya kulit merah, gatal-gatal ataupun adanya pembengkakan. Dari hasil uji iritasi tersebut dapat disimpulkan bahwa sediaan masker peel-off yang dibuat aman untuk digunakan. Hasil Uji Iritasi dapat dilihat pada table 4.3

Tabel 4.3 Hasil Uji Iritasi

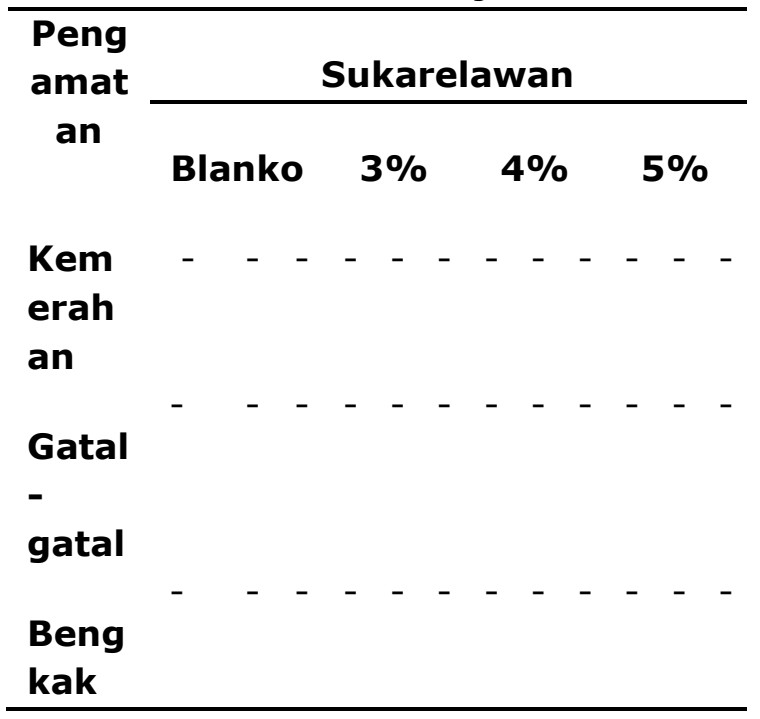

\section{Hasil Uji Waktu Mengering}

Berdasarkan hasil uji waktu mengering yang dilakukan oleh sukarelawan di dapatkan hasil 30 menit untuk benar benar kering untuk semua konsentarsi. Dari hasil uji tersebut dapat disimpulkan sesuai dengan literature yang menyatakan persyaratan waktu mongering yaitu $\pm 15-30$ menit (Slavtcheff,2000).

\section{Hasil Uji Kelembapan}


Hasil Uji Kelembapan dapat dilihat pada table 4.4

Tabel 4.4 Hasil Uji Kelembapan Kulit dengan Skin Analyzer

\section{N Konse Sukar Percobaan(\% \\ o ntrasi elawa \\ n

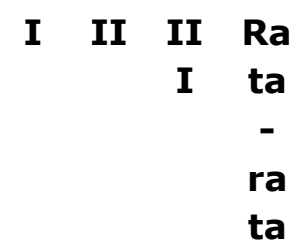

$\begin{array}{lllllll}1 & \text { Blanko } & 1 & 4 & 4 & 4 & 41\end{array}$

$1, \quad 1,2, \quad, 5$

240

$\begin{array}{lllll}2 & 3 & 3 & 3 & 37\end{array}$

$7,7,7, \quad 5$

$\begin{array}{lll}3 & 5 & 8\end{array}$

$\begin{array}{lllll}3 & 3 & 3 & 3 & 38\end{array}$

$8,8,8,3$

245

$\begin{array}{lllllll}2 & 3 \% & 1 & 4 & 4 & 4 & 44\end{array}$

$3,4,4,2$

926

$\begin{array}{lllll}2 & 4 & 4 & 4 & 45\end{array}$

$5,5,5, \quad 4$

248

$\begin{array}{lllll}3 & 4 & 4 & 4 & 46\end{array}$

$6,6,6,2$

$\begin{array}{lll}0 & 3 & 5\end{array}$

$\begin{array}{lllllll}3 & 4 \% & 1 & 4 & 4 & 4 & 48\end{array}$

$8,8,8,6$

$\begin{array}{lll}6 & 6 & 7\end{array}$

$\begin{array}{lllll}2 & 4 & 4 & 4 & 47\end{array}$

$7,7,7,7$

$\begin{array}{lll}6 & 8 & 9\end{array}$

\begin{tabular}{|c|c|c|c|c|c|c|}
\hline & & 3 & 4 & 4 & 4 & 49 \\
\hline & & & $\begin{array}{l}9, \\
2\end{array}$ & $\begin{array}{l}9, \\
3\end{array}$ & $\begin{array}{l}9, \\
5\end{array}$ & ,3 \\
\hline \multirow[t]{9}{*}{4} & $5 \%$ & 1 & 5 & 5 & 5 & 52 \\
\hline & & & 1, & 1, & 2, & 0 \\
\hline & & & 7 & 9 & 6 & \\
\hline & & 2 & 5 & 5 & 5 & 53 \\
\hline & & & 3, & 3, & 3, & 7 \\
\hline & & & 6 & 7 & 8 & \\
\hline & & 3 & 5 & 5 & 5 & 50 \\
\hline & & & 0, & 0, & 1, & 6 \\
\hline & & & 0 & 8 & 0 & \\
\hline \multirow[t]{9}{*}{5} & Kontro & 1 & 5 & 5 & 5 & 52 \\
\hline & IPositif & & 2, & 2, & 3, & 6 \\
\hline & & & 4 & 6 & 0 & \\
\hline & & 2 & 5 & 5 & 5 & 50 \\
\hline & & & 0 , & 0, & 1, & 9 \\
\hline & & & 6 & 8 & 5 & \\
\hline & & 3 & 5 & 5 & 5 & 57 \\
\hline & & & 7, & 7, & 7, & , \\
\hline & & & 6 & 8 & 9 & \\
\hline \multirow[t]{9}{*}{6} & Kontro & 1 & 1 & 1 & 1 & 12 \\
\hline & INegat & & 1, & 2 & 3, & 6 \\
\hline & if & & 6 & 3 & 9 & \\
\hline & & 2 & 1 & 1 & 1 & 15 \\
\hline & & & 2, & 4, & 7, & \\
\hline & & & 3 & 9 & 8 & \\
\hline & & 3 & 3 & 3 & 3 & 36 \\
\hline & & & 5, & 7, & 7, & 7 \\
\hline & & & 6 & 1 & 6 & \\
\hline
\end{tabular}

Berdasarkan tabel 4.3 diatas dapat dilihat bahwa semakin tinggi konsentrasi ekstrak yang digunakan pada sediaan masker peel-off ekstrak etanol daun sawi hijau, maka semakin tinggi pula kemampuan untuk melembabkan kulit. Hal ini terlihat dari konsentrasi $5 \%$ yang lebih banyak mengandung ekstrak daun sawi hijau, 
dimana ekstrak daun sawi hijau terdapat senyawa flavonoid yang berfungsi untuk melembabkan kulit. Konsentrasi 5\% memiliki tingkat kelembapan kulit sama dengan control positif yakni masker peel-off bengkoang yang dijual dipasaran. Hal ini membuktikan bahwa konsentrasi ekstrak etanol daun sawi yang digunakan dalam sediaan masker peeloff mampu memberikan kelembapan kulit yang baik.

Menurut Purba (2016), criteria kelembapan kulit adalah $<40 \%$ kurang lembab, 40-60\% lembab, $>40 \%$ sangat lembab. Dapat disimpulkan semua konsnetrasi dapat melembabkan kulit dengan kategori lembab.

\section{Analisis Data}

\section{Hasil Uji Anova}

Berdasarkan hasil output diketahui bahwa terjadi perbedaan rata-rata kelembapan kulit pada setiap konsentrasi, hal ini dibuktikan dengan nilai sig 0,000 atau $p<0,005$ sehingga diputuskan bahwa variabel memiliki perbedaan

\section{Hasil Uji Post Hoc Tukey}

Berdasarkan hasil uji Post Hoc Tukey dapat dilihat bahwa konsentrasi 5\% memiliki rata-rata kelembapan yang paling baik yaitu sebesar 52,100 mendekati rata-rata kelembapan kontrol positif yaitu sebesar 53,733 dibandingkan dengan konsentrasi lain.

\section{KESIMPULAN}

Berdasarkan hasil penelitian yang telah dilakukan dapat disimpulkan bahwa:

1. Rerata nilai kelembapan kulit ekstrak etanol daun sawi hijau konsentrasi 3\% adalah 44,2, 45,4 dan 46,2

2. Rerata nilai kelembapan kulit ekstrak etanol daun sawi hijau konsentrasi $4 \%$ adalah 48,6, 47,7 dan 49,3

3. Rerata nilai kelembapan kulit ekstrak etanol daun sawi hijau konsentrasi 5\% adalah 52,0, 53,7 dan 50,6

4. Dari hasil uji Post Hoc Tukey dapat dilihat bahwa konsentrasi 5\% memiliki rata-rata kelembapan yang paling baik yaitu sebesar 52,100 mendekati rata-rata kelembapan control positif yaitu sebesar 53,733 dibandingkan dengan konsentrasi yang lain.

\section{DAFTAR PUSTAKA}

Achroni.(2012).Semua Rahasia Kulit Cantik dan Sehat Ada Disini.Yogyakarta:Javalitera.

Aramo.(2012).Skin and Hair Diagnosis System.Sungham:AramHuvisK oreaItd.Hal.1-10.

Aruan,Linda.(2017).Formulasi Sediaan Masker Peel-Off yang Mengandung Ekstrak Buah Apel Hijau (Malusdomestica Borkh.) Sebagai ANTI-SKIN-AGING.

Cahyono.(2003).Tehnik dan Strategi Budidaya Sawi Hijau (PatTsai).Jakarta:Yayasan Pustaka Nusantara Aksara.

Darmawan.(2013).Anti Aging Rahasia Tampil Muda Disegala Usia.Yogyakarta:Media Press indo.

Departemen

Kesehatan

RI.(2000).Acuan Sediaan

Herbal.Jakarta:Direktorat

Jendral Pengawasan Obat dan Makanan.

Direktorat Gizi.(1979).Kandungan Gizi dalam $\quad 100 \mathrm{~g}$ Sawi Hijau.Departemen Kesehatan RI

Ditjen POM RI.(1995).Farmakope Indonesia Edisi 
IV.Jakarta:Departemen Kesehatan RI.

GargA,DeepekaA,GargS.SinglaAk.(200) . Spreading of Semisolid Formulation.Pharmaceutical Technology.

Grace,F.X,C.Darsika,K.V.Sownya,K.Sug anya amd S.Shanmuga Nathan.(2015).Preparation and Evaluation of Herbal Peel Off Face Mask. American Journal of Pharmtech Research.(5).33-36.

Harry.(1973).Harry's Cosmeticology. Edisi

Keenam.Newyork:Chemical

Publishing Co.,Inc.Hal:103109.

Harry. (2000). Harry's Cosmeticology. Newyork : Chemical Publishing.

Haryanto et. al. (2002). Bertanam Selada dan Sawi. Jakarta : Penebar Swadaya.

Irwan. (2005). Pengaruh Dosis Kascing dan Broaktivator terhadap Pertumbuhan dan Hasil Tanaman Sawi (Brassica juncea L.) yang dibudidayakan secara organic. Jurnal Pertanian. Bandung: Jurusan Budidaya Pertanian Fakultas Pertanian UNPAD.

Istarofah,Zuchrotus. (2017). Pertumbuhan Tanaman Sawi Hijau dengan Pemberian Pupuk Kompos Berbahan Dasar Daun Paitan. Yogyakarta: Universitas Ahmad Dahlan.

Kaban. (2015). Uji Aktivitas Antibakteri Ekstrak Etanol Daun Binara dan Ekstrak Etanol Daun UlamUlam terhadap Bakteri Staphylococcus aureus dan Escherichia coli). Skripsi. Medan: Fakultas Farmasi Universitas Sumatera Utara.

Kloppenburg. (2009). Petunjuk Lengkap Mengenai Tanam-Tanaman di Indonesia dan Khasiatnya sebagai Obat-Obatan
Tradisional. Yogyakarta: Yayasan Dana Sejahtera.

Kuncari. (2014). Evaluasi Uji Stabilitas Fisik dan Sinergis Sediaan Gel yang mengandung Minoksidil, Apigenin dan Perasan Herba Seledri (Apium graveolers L.) Bul. Peneliti Kesehatan. 42(4):214.

Marbun, R., Situmorang, N., \& Wahyuni, S. (2018). The efect of immunomodulator by extract ethanol of herba binara (artemisia vulgaris I.) Toward the response of delayed-type hypersensitivity in rat male. Jurnal Penelitian Farmasi \& Herbal, 1(1), 17-21. Retrieved from http://ejournal.delihusada.ac.i d/index.php/JPFH/article/view/ 59

Margiyanto. (2007). Budidaya Tanaman Sawi. Jakarta: Penebar Swadaya.

Mitsui. (1997). New Cosmetic Science. Amsterdam: Elsevier. Pp. 357362.

Muliyawan . (2013). A-Z tentang Kosmetik. Jakarta: PT Elex Media Komputindo.

Nova. (2012).Formulasi Ekstrak Metanol Kulit Manggis (Garcinia mangostanta L) Pada Uji Iritasi Primer. Skripsi. Fakultas Farmasi. Yogyakarta: Universitas Santana Dharma.

Nurul. (2018). Formulasi Sediaan Sabun Mandi Padat dengan Ekstrak Etanol Daun Sawi Hijau (Brassica juncea L) sebagai Pelembab Kulit. Lubuk Pakam: Institut Kesehatan Medistra Lubuk Pakam.

Pahlevi, Pramadana, Juswono, Widodo. (2014). Studi Pengaruh Sawi Hijau Terhadap Jumlah Radikal Bebas pada Mie Instan. Malang: Universitas Brawijaya 
Pracaya. (2011). Bertanam Sayur Organik. Jakarta: Penerbar Swadaya.

Prima, Nadia. (2017). Pengaruh Penggunaan Masker Buah Semangka Terhadap Kulit Wajah Kering. Padang: Universitas Negeri Padang.

Purba, R.Y. (2016). Skrining Fitokimia dan Penggunaan Buah Belimbing manis Sebagai Pelembab dalam Krim cair Tangan dan Badan. Skripsi. Medan. Universitas Tjut Nyak Dhien.

Putro. (1997). Agar Awet Muda. Purwodadi: Trubus Agrisarana.

Rahmawati, dkk. (2015). Formulasi dan Evaluasi masker Wajah Peel-Off Mengandung Kuersesin dengan Varian Konsentrasi Gliserin dan Gliserin. Media Farmasi.

Rahmi. Al. (2016). Formulasi dan Evaluasi Sediaan Masker Gel Peel-Off Ekstrak Daging Buah Tomat (Lycopersicum esculentum Mill) dengan Perbedaan Konsentrasi PVA sebagai Basis. Ciamis: STIKes Muhammadiyah Ciamis.

Rahim. (2014). Formulasi Masker PeelOff Ekstrak Rimpang Rumput Teki (Cyrus rotundus L.) Sebagai Anti Jerawat. Prosiding Saminar Nasional dan Workshop Perkembangan Terkini Sains Farmasi Klinik IV. Hal 65.

Ratnamila, Mimil. (2011). Penggunaan Sari Wortel (Daucus carota L.) yang Dipekatkan dalam Sediaan Krim Pelembab. Medan: Universitas Sumatera Utara

Rieger. (2000). Harry's Cosmetology $8^{\text {th }}$ edition. Newyork: Chemical Publishing Co.Inc.
Rukmana. (2007). Bertanam 30 Jenis Sayur. Jakarta: Penebar Swadaya.

Rowe, R.C.,Paul,J.S., dan Marian. (2009). Handbook of Pharmaceutical Excipients $5^{\text {th }}$ ed. Landon: The Pharmaceutical Press.

Septiani. (2011). Formulasi Sediaan Masker Gel Antioksidan dari Ekstrak Etanol Biji Melinjo (Gnetum gnemon linn.). Bandung: Universitas Padjajaran.

Slavtcheff. (2000). Komposisi Kosmetik untuk Masker Kulit Muka Indonesia. Patent 2000/00049B.

Sunarjono. (2004). Bertanam 30 Jenis Sayur. Jakarta: Penebar Swadaya.

Tranggono. (2007). Buku Pegangan IImu Pengetahuan Kosmetik. Jakarrta: PT Gramedia Pustaka Utama.

Pulungan, A., Sitepu, D., \& Sinaga, D. (2018). Formulation of Ointment of Antibactery Ethanol Extract of Torch Ginger (Etlingera elatior) Against Bacteria Staphylococcus aureus. Jurnal Penelitian Farmasi \& Herbal, 1(1), 1-5. Retrieved from http://ejournal.delihusada.ac.i d/index.php/JPFH/article/view/ 30

Vieira, Rafael Pinto . (2009). Physical and Physicochemical Stability Evaluation of Cosmetic Formulation Containing Soybean Ekstrak Fermented by Bifidoba Cterium animali. Brazilian: Journal of Pharmaceutical Sciences vol.45.

Wasitaatmadja. (1997). Penuntun IImu Kosmetik Medik. Jakarta: UI Press. 
Jurnal Farmasi, e-ISSN: 2655-0814

Vol. 2 No.1 Edisi Mei-Oktober 2019

http://ejournal.medistra.ac.id/index.php/JFM

Received: 05 September 2019 :: Accepted: 14 September 2019 :: Published: 31 Oktober 2019 